\title{
Correction to: Ignac Semmelweis-Father of Hand Hygiene
}

\section{Uvi Tyagi $^{1} \cdot$ Kailash Chander Barwal ${ }^{1}$ (i)}

Published online: 27 June 2020

(C) Association of Surgeons of India 2020

\section{Correction to: Indian Journal of Surgery https://doi.org/10.1007/s12262-020-02386-6}

The article "Ignac Semmelweis-Father of Hand Hygiene", written by Uvi Tyagi and Kailash Chander Barwal, was originally published electronically on the publisher's internet portal (currently SpringerLink) on 21 May 2020 with open access.

With the authors' decision to step back from Open Choice, the copyright of the article changed on June 2020 to $($ C) Association of Surgeons of India 2020 and the article is forthwith distributed under the terms of copyright.

Publisher's Note Springer Nature remains neutral with regard to jurisdictional claims in published maps and institutional affiliations.

The online version of the original article can be found at https://oi.org/ $10.1007 / \mathrm{s} 12262-020-02386-6$

Kailash Chander Barwal

kailashbarwa129@gmail.com

1 Department of Urology, Indira Gandhi Medical College,

Shimla, Himachal Pradesh, India 